\title{
Ethnographic museums and essentialist representations of Galician identity
}

\author{
Xerardo Pereiro Universidade de Trás-os-Montes e Alto Douro \\ Manuel Vilar Asociación Galega de Antropoloxía
}

\begin{abstract}
This article presents a critical perspective on Galician ethnographic museums as a mechanism for the representation of cultural identities. It argues that the legislation pertaining to ethnographic museums can be seen, in part, as constituting a definition of identities. It also discusses the models of and for the creation of museums known as 'ethnographic', the official recognition of this type of museum in Galicia, and the corresponding construction of a hegemonic image of Galician identities. Finally, the article considers the process of producing and consuming ideas about Galician self-identity in 'ethnographic' museums.
\end{abstract}

\section{Introduction}

This article focuses on the social processes that underlie the selection of cultural artefacts for the establishment of museums labelled as 'ethnographic museums' by their creators and visitors. As a result of a study of the counter-hegemonic role of some community museums, the following presents an analysis of the role of hegemonic ethnographic museums and their promotion of a notion of cultural homogeneity - a notion that is also taken up by those community and regional museums not officially recognized as 'ethnographic' by government criteria. The geographical context studied is Galicia, in the northwest of the Iberian Peninsula, where the authors have been engaged in anthropological fieldwork for several years. Both have worked as researchers in several Galician museums, especially in the Ethnographic Park (Parque Etnográfico) in Allariz in the province of Ourense and the Ethnographic Museum of San Paio de Narla, which is an extension of the Provincial Museum of Lugo. This project is based on extensive anthropological fieldwork undertaken during the period 1997-2006 in Galician ethnographic museums and also on archival data found in the Penzol Foundation (in the city of Vigo), the Museum of the Galician People (Museo do Pobo Galego) and the Museum Section of the Xunta de Galicia.

The analysis focuses on the images on display and the accompanying ideological discourses in museums labelled as 'ethnographic'. Although they are still embedded in Galician culture, these images have been 'ruralised' for consumption by urban people. The article begins with an examination

\section{Keywords}

ethnographic

museums

anthropology

images

identities

heritage

Galicia (Spain) 
of the administrative and legal categories that influence the creation of displays in Galician ethnographic museums. It then moves on to an analysis of the motivations and processes behind the creation and selection of these representations, and their reception by museum visitors.

Galicia is one of the 17 autonomous regional governments that were created in the 1980s. In the Spanish Constitution Galicia is framed as one of the 'historic nationalities' of Spain, along with Catalonia and the Basque Country. It has nearly 3 million inhabitants living in four provinces: A Coruña, Lugo, Ourense and Pontevedra. Galicia is world-renowned because of pilgrimages to Santiago de Compostela, the regional capital. Although Galicia was historically dominated by a rural economy, in the last five decades it has experienced a very strong process of urbanization, in social, cultural, political and economical terms (Pereiro Pérez 2005: $34)$. In the census of 2006, 67.7 per cent of Galicians were registered as living in urban settlements of over 10,000 inhabitants (Instituto Galego de Estatística 2007).

The main aim of this article is to analyze the production of essentialist representations of Galician identity in ethnographic museums. In anthropology, visual and verbal representations are a very good arena for understanding ideological discourses and metaphors about cultural identities. The study found many museum exhibits to be self-referential and selfabsorbed and utterly opaque with regard to the possibility of creating 'contact zones' between Galicians and people from other cultural backgrounds inside these museums - such zones frequently being established in tourism and heritage sites (Clifford 1999: 238). On the assumption that ethnographic museums are mirrors that make symbolic use of memory and history, one can argue that the 'others' in Galician ethnographic museums are being portrayed in a disorderly manner and in terms of a generic 'ruralised' and primitivized past. Additionally, there is a distinct lack of anthropological discourses on relational and transnational identities in these museums (Hannerz 1998). Overall, modern anthropological discourses are not being applied in ethnographic museums in Galicia and elsewhere. The self-images representing 'Galician' identity are in debt to the society and to people's efforts made in the past (Boniface and Fowler 1993), being in essence a way of acknowledging these. Moreover, they respond to tourists' interests and the processes of restructuring in farming and post-industrial economies (Sierra Rodríguez 2002: 16). Based on Korff's (2002) perspective, Galician ethnographic museums can be considered to be museums of internal ethnology, in which the dialectic between identity and otherness has been achieved by promoting the authority of self and local identity with links to the rural past.

Museum policies have thus focused on averting the 'loss' of certain assets that have been mystified as 'rural' or 'ethnographic'. Those symbolic links, misleading and simplistic in the extreme, have been inspired by museums that rely on crystallized Galician anthropological discourses produced between the 1930s and the 1970s. The production of ethnographic 
texts and establishment of numerous new museums and travelling exhibits are currently becoming widespread in Galicia. In spite of that, it seems as though we may have to wait for many more years before contemporary anthropological discourses and research will come to have a notable impact on Galicia's museums.

The article is organized in five sections: first, ethnographic museum legislation is analyzed as framing a definition of identities; second, there is a discussion of the models of, and for, the implementation of ethnographic museums; third, the official recognition of this type of museum in Galicia and the construction of a hegemonic image of Galician identities is outlined; fourth, there is a discussion of the expansion of the idea of the 'ethnographic' museum in Galicia; and fifth, there is a consideration of the link between the representations produced by the ethnographic museums and how these are interpreted and consumed by visitors.

\section{Museums and legislation in Galicia}

Protecting the nation's cultural heritage has had a chequered history in Spain. The Second Republic took steps to do so, passing the Ley del Patrimonio Artístico Nacional (the Law of National Artistic Heritage) on 13 May 1933 (García Fernández 2007). But it was short-lived, being abolished by the Franco dictatorship, which did not replace it. Thus Spain's cultural heritage remained unprotected until after the return to democracy, when in 1985 the Socialist government finally addressed the issue with its Ley del Patrimonio Histórico Español (the Law of Spanish Historical Heritage) (García Fernández 1987). Meanwhile, the country had become a quasifederal state and the Galician Autonomous Community (Xunta de Galicia) was created in 1981. Its devolved powers allowed the region to be selfgoverning over matters of Galician historical heritage and culture, and its legislature was quick to pass new laws to strengthen protection.

A formal legal definition of the term 'museum' will help us understand how images on display represent ourselves and 'others'. The International Council of Museums (ICOM) provides widely accepted definitions, and one of these was used in the Law on Galician Cultural Heritage (Lei do Patrimonio Cultural de Galicia) of 1995:

\footnotetext{
Museums are institutions of a permanent character; open to the public; with no profit motive in mind; directed towards the promotion and cultural development of a community as a whole, by means of the collection, acquisition, inventory, cataloguing, conservation, research, dissemination, and display, in a scientific, didactic, or aesthetic way, of collections or groups of culturally relevant heritage assets; which bear witness to activities undertaken by human beings, or taking place in the natural environment; with research, educational, recreational, or scientific and cultural promotion purposes (Article 67)

(Xunta de Galicia 1995; this and other translations in the article are by the authors and editors unless otherwise indicated).
} 
Section Two of the article specifies the functions to be fulfilled by museums:

1. Conservation, cataloguing, restoration, and organized exhibition of the collections.

2. Research in the fields related to the museum's collections, speciality, or specific cultural environment.

3. Periodic organization of exhibitions, aimed at specialized audiences and the general public.

4. Preparation and publication of catalogues and monographs concerning the museum's collections.

5. Development of didactic activities concerning the museum's contents.

6. Any other functions that might be entrusted to the museum by the statutory laws or other legal rules or stipulations.

(Xunta de Galicia 1995)

Article 68 introduces the concept of a 'visitable collection'. Museums are required to have regular visiting hours convenient for the general public and researchers. Thus, the term museum should not be used for collections which do not meet these requirements, even if they have clearly defined cultural goals and significant social and cultural activities take place in them.

Article 69 specifies that the creation, authorization, and registration of new museums must be approved by the Council of the Galician Autonomous Government (Consello da Xunta de Galicia). This Council is also responsible for defining the museum's territorial scope and thematic contents (Art. 69.1). For a collection to be registered as a 'museum' by the Galician Autonomous Government, 'an application must be submitted to the General Directorate for Cultural Heritage (Dirección Xeral de Patrimonio Cutural), which is part of the Department of Culture (Consellería de Cultura), and the following requirements have to have been met: an inventory of the collection's assets; a study of the storage and display facilities available, including details on such spaces as libraries and shops; a program for the museum's development; and finally, an outline of staff and funding needs'. According to Pérez Outeiriño (1997: 23), such rules are aimed at 'preventing the creation of ephemeral, precarious and redundant institutions and at averting conflicts over the materials to be displayed'.

According to the legal definition, then, museums in Galicia are permanent institutions designed to promote cultural development through the collection and display of culturally relevant heritage assets. Under this definition, museums are to be not just safe storage areas, but also sites for research and cultural activities with an educational emphasis. They are to facilitate a democratic access to culture.

\section{Ethnographic museums}

Legislation pertaining to ethnographic museums can be understood as a way of defining images of identity. Museums and cultural heritage have played a major role in economic development in Europe, especially since 
the 1970s. In England, 500 local ethnographic museums were set up during the 1980s, largely as a reaction to the harsh effects of the industrial crisis (Walsh 1992). In the same time period, the concept of 'ecomuseum' (Rivière 1989; Poulot 1994) was coined in France with the purpose of overcoming the agrarian crisis in rural areas. As some authors have argued, in the last few decades it has been common to conserve things just as they have become ever more provisional and disposable (Augé 1993). Museums stand out as an example of permanence in an age of fleetingness (Fernández de Rota 1996). For this reason, among others, museums are set to become major sociocultural centres (Sierra Rodríguez 1996). In the Iberian Peninsula, however, the concept of museums and cultural heritage forming a part of economic development strategies only became popular in the 1990s.

Museums are needed not only to assist with the socio-cultural reemergence of certain areas plunged into economic crisis, but to satisfy the deep human need to preserve parts of collective memory, with the purpose of attaining some sort of cultural continuity and transmitting the most cherished values of our cultural heritage to the coming generations. Museums play a key social role, namely that of interpreting our lifestyles and the lifestyles of others in an increasingly multicultural world. In the authors' perspective they are a cultural industry (Adorno and Horkheimer 1979). Thus, should they not exist, museums would have to be invented. Prior to setting up a new museum, a number of artefacts that are liable to take part in a cultural heritage creation process must be selected. Communities need such heritage creation processes in order to achieve certain goals in tourism, education and social reproduction (KirshenblattGimblett 1998; 2001). Yet many so-called ethnographic museums are still nothing but exhibitions - stylized though they may be - of a number of objects fallen into disuse and seen by the visitors as 'survivals', or objects from the past (Stocking 1985: 4).

Lack of definition is then the first problem we have to confront when dealing with museums defined as ethnographic, ethnological or anthropological. James Clifford (1995: 149) reminds us how difficult it is to differentiate between art and anthropology museums and the problems involved in such a distinction. A handful of typologies of ethnographic museums are available (Llopart 1994: 10-13), but these can be narrowed down to three major paradigms (Castro Seixas 1997).

The first paradigm can be called 'classic ethnographic museums' (Castro Seixas 1997). These museums are characterized by being closed spaces, of cave-like, store or laboratory appearance, where objects and walls play a prominent role, are focused on the past, and designed with a passive visitor in mind.

The second paradigm is based upon a spirit of renewal and features the so-called 'setting museums', 'open-air museums' and 'eco-museums'. These are museums of an open character that focus on concepts such as community, territory, identity and testimony. These museums tend towards the suppression of walls or barriers, and stress present-day experiences. 
1 The Introduction to the themed issue discusses the birth of the nationalist movement in Galicia.
In this second paradigm of museum, the visitor is active, a dweller and a participant.

Recently, because of a crisis in museological representations and the fuzziness when it comes to distinguishing between 'museable' and 'non museable' assets, a third type of museum is emerging. This type of museum is identified by three names: 'rupture museums', 'dialogical museums' and 'community museums' (Castro Seixas 1997). In all three, members of the public cease to be conceived of as mere visitors or intruders only tolerated for a period of time, and play a new role as participants in certain dialogues, involving local knowledge, imagination, sensory perception and interactions. Instead of focusing on classification, these museums provide a guided and interactive discovery process. In other words, they are not centred around objects but people, and are thus museums of ideas, rather than museums of things.

These three conceptions of what a 'ethnographic museum' is co-exist, since the process of change is not linear or unidirectional. As we shall see in detail, the representations of identity in Galician ethnographic museums are conditioned by the extent to which those museums fit into any of the above-mentioned paradigms.

Here the authors are using the term 'ethnographic' with the aim of stressing a 'emic' conception of the musealization processes, reflecting the point of view of the promoters and users of museums called 'ethnographic'. In anthropology and related fields, the term 'emic' refers to the insider or 'local' point of view (Pike 1967 [1954]). The focus is on how the word 'ethnographic' is understood by the promoters and mediators of museum development. Following Korff (2002), musealization can be defined as a process involving the invention, activation, conservation, and appreciation of a number of cultural artefacts, subsequently labelled as museums by the promotional agents. Those designing and promoting Galician ethnographic museums tend to use the word 'museum' rather than 'collection' for their assets - because of the higher prestige of the former - and irrespective of any scientific criteria or ICOM's standards. Instead, they focus on creating a product intended for tourist consumption and also political gain. The following section examines how Galician museums were institutionalized during the 20th century.

\section{The institutionalization of 'ethnographic' museums in 20th century Galicia}

This section outlines certain problems concerning the 'official' recognition of Galician ethnographic museums, focussing on those governmental policies relating to the creation of ethnographic museums and exhibitions of cultures (Karp and Lavine 1991). In the case of Galicia, as in other parts of Europe, the process of stocking museums (Stocking 1985) with ethnographic objects must be understood in the context of the birth of the Galician nationalist movement. ${ }^{1}$ The ethnographic material together with the archaeological material has the objective of linking museums with 
tourism. One example was the creation of the first recognized 'ethnographic' museum, the Museum of the Mondariz Spa created by Enrique Peinador in 1905 to attract upper class tourism, which holds art and archaeology exhibits as well as ethnographic ones (Pérez, Serrano and Vilar 1997).

The first serious attempts at creating a 'national museum' in Galicia designed to display the material forms of a differentiated culture - dates from the years preceding the Spanish Civil War of 1936-39. Galician nationalist intellectuals thought that a national museum would strengthen Galicia's identity and culture, thus smoothing the path toward home-rule. The body designed to undertake the museum's creation was the Seminar for Galician Studies (Seminario de Estudos Galegos, or S.E.G.). This project emerged from Galician civil society with the purpose of dignifying Galician culture in a period when the Spanish state was controlled by the military government of Gen. Miguel Primo de Rivera, which suppressed political freedoms. The beginning of the museum's collection can be dated to 1926 (Fariña Busto 2004). During the academic year of 1930-31, the collection was housed in a hall (in the Palace of Fonseca) donated by the University of Santiago de Compostela. The ethnographer Xaquín Lorenzo (also known by the Galician spelling Lourenzo) and a clergyman named Jesús Carro were put in charge. However, in 1936, when the Spanish Civil War broke out, the initiative was paralyzed. The promoters of the museum were executed, exiled or forced to wait for better times to put their idea into practice. We owe to Jesús Carro an inventory of the holdings prior to the Franco regime's expropriation of them and their partial transfer to Santiago's university. Jesús Carro wrote the following account of a new transfer of the museum's holdings:

To mark the celebration [in Santiago de Compostela] of the Feminine Section's Congress [i.e., the Sección Femenina of the fascist political party], they intend to use the Coffered Hall - or old refectory of Fonseca's Palace - for holding the sessions. Since the Seminar's Ethnographic and Archaeological Museum was located in that same place, all the collection's objects were removed to a storage room in the same building.

[Xosé Carro’s letter to Xosé Ramón Fernández Oxea, dated 9/1/1943 (A. Mato 2001)]

By 1975, seven ethnographic museums were officially registered in Galicia (Fariña Busto 1975a,b: the Regional Costume Museum in Betanzos (province of A Coruña); the Padre Sarmiento Institute Museum in Santiago de Compostela; the Casa de la Troya Museum in Santiago de Compostela; the Provincial Museum of Lugo; the Pallozas' Museum (Mountain Areas Museum) in O Cebreiro, province of Lugo; the Ribeiro Museum (Valley Museum) in Ribadavia, province of Ourense); and lastly the Sea Museum of the Massó Family in Bueu, province of Pontevedra.

After Franco's death in 1975 and the ensuing end of the dictatorship, the idea of creating a Galician national museum was reintroduced by Galician intellectuals such as Xaquín Lorenzo. Thus, a Museum of the 
Galician People (Museo do Pobo Galego) was established in Santiago de Compostela in 1976 'with an intention of carrying out the Seminar's old aspiration to create an Ethnographic museum in Galicia' (Lorenzo 1978: 52). The museum was created by Xaquín Lorenzo and other ethnographers, including Filgueira Valverde, Taboada Chivite and Antonio Fraguas (Sierra Rodríguez 1999; Calo Lourido 2004). All of them had belonged to the Seminar for Galician Studies until its violent end and began to work in association with new ethnographers who were born after the Civil War. At this time, anthropology was sought out for its institutional status even though its methods were less known by the ethnographers who had been educated in folkloristic methods before the Spanish Civil War. The Museo do Pobo Galego and the research carried out by the above-mentioned ethnographers would provide a model for the smaller museums created later in Galicia during the democratic period.

The 1993 official list of Galician museums mentions fifteen museums with ethnographic holdings, both thematic museums and museums with varied assets. López Redondo, López de Prado Nistal and Lemos Ramos (1993) and Sierra Rodríguez (2002) critiqued this typology of ethnographic museums, the latter's contribution reading as follows:

That typology is contradictory insofar as museums are classified in terms of their collections' material contents, instead of taking into account their objectives and guiding discourses. Thus, certain museums have been classified in official lists as solely ethnographic museums, even though they lack an [up-to-date] anthropological approach in their discourses, objectives, the training and role of their personnel, their bibliographic resources, as well as a lack of funding for documentation.

(Sierra Rodríguez 2002: 5).

In this study, the authors took up Sierra Rodríguez's critique and, through fieldwork in museums and archival research, formulated a list of all of the museums considered to be 'ethnographic' by their organizers and visitors, whether officially recognized as such or not. The following section turns to some specific examples of such museums.

\section{The expansion of the idea of the 'ethnographic' museum in Galicia}

Since this research began in 1997 , the list has increased to 61 museums by 2006, including all museums and ethnographic collections, whether they are recognized or not by the Galician Autonomous Government. 'Emic' criteria (Pike 1967 [1954]) rather than official government definitions were applied, taking into account every museum that defines itself as ethnographic. Only those developed abroad in migration contexts where Galician identity has played an important role have been left out. The list illustrates the current scale of the 'ethnographic' phenomenon in Galicia and indicates a significant interest in such institutions on the part of Galician society. 
This increase in the number of museums is clearly related to the introduction of democracy to Spain, which enriched civil society. Yet some of these have not been recognized by the Xunta de Galicia, since their creation depended on the wishes of certain individual collectors or was promoted by local, political or cultural entities. If one looks at the most widely read Galician newspaper ( $L a$ Voz de Galicia), a variety of so-called 'museums' is listed. Although some of these are just small collections, they can be varied, surprising, odd, evocative, and interesting. There is one devoted to handicrafts made by retired sailors in Fisterra; and another to Ramón Caamaño's machines and photographs. Ramón Caamaño is considered the main photographer of the 'Coast of Death' (A Costa da Morte) notorious since the environmental disaster of the fuel tanker 'Prestige' in November 2002. He began to take photographs when he met the American photographer Ruth Matilda Anderson at Muxía in 1924. The museum of the sculptor and poet Asunción Antelo displays sculptures with tree-like roots, while another shows sculptures made out of pebbles and the remains of shipwrecks collected by 'Man' - a German who withdrew to the seaside village of Camelle on the same coast.

These sorts of 'unofficial' museums are interesting for two reasons, namely the role played by civil society in their creation and the way that they contrast with museums promoted or supported by the government. It is common knowledge in Galicia that some institutions are called 'museums' due to political interests and pressures, rather than for the merits or quality of their assets or discourses. Besides, the word 'museum' is chosen by their promoters for its symbolism and the consequent higher social status and degree of prestige associated with it. To illustrate these points two instances of museums not widely recognized as such are now presented.

The first collection of ethnographic material to be discussed is located in the municipality of Castro de Rei in the province of Lugo, and belongs to the so-called 'Terra Chá' (the Flat Land), a farming area in the Miño River watershed. The collection - intended to be permanent - was assembled by the local association 'Amigos da Feira' (Friends of the Fair), with the help of the parents' association of 'Ramón Falcón' State School. Amigos da Feira successfully revived a fortnightly local fair in Castro de Rei, long-since cancelled due to the drawing power of the Meira town fair. It also organized a homage to 'zoqueiros' (clog-makers), coinciding with the inauguration of the new ethnographic exhibition.

The materials collected are displayed inside an unused school building in a high covered courtyard. When the authors visited the collection in 1999, there was not enough room for its storage needs, but the organizers were willing to expand it and turn the exhibition into a permanent collection, since the school had 'too much space and no kids' as they put it. They were confident about making it permanent too. 'Labelling' all of the pieces was one of their top priorities, meaning, as the authors understood it, creating an inventory and rescuing those pieces from oblivion, since some of them had fallen out of use before living memory. How did this 
collection emerge? Allegedly, the initiative was undertaken in a 'rather unexpected way' by the association 'Amigos da Feira'. They simply started to ask their neighbours for pieces to be included in an exhibition presented in an 'unusual' sort of way. The exhibition was arranged in less than a month's time, and the association members felt encouraged to go on collecting materials. They intend to revitalize their locality through the promotion of activities, such as the recovery of the town's fair and old trades and the ethnographic exhibition itself. The collection is structured to a certain degree, including sections devoted to specific farming activities, such as cereal crops; honey, wool and (flax) linen production; traditional houses; old trades, and so forth. The distribution of the materials was inspired by the ideas of Xaquín Lorenzo, a renowned Galician ethnographer, whose most important work History of Galiza, one volume of which deals with material culture, was published in 1962 thanks to the patronage of Galician emigrants and exiles in Argentina. His work aimed at systematizing the so-called Galician popular culture, and it still provides a model for museum and heritage design. Additionally, Castro de Rei's collection features a number of out-of-service modern farming implements including wooden ploughs and oxen carts, which tend to be excluded by classic ethnographic museums on the assumption that they disrupt the supposedly unchanging character of traditional farm tools. Breaking with this 'classic' approach, the promoters of Castro de Rei's initiative considered such modern pieces to be equally representative of the locality's collective memory.

Another example of an 'unofficial museum' is an ethnographic collection in Ponte do Porto, a small town on the shores of a river that flows into the Camariñas estuary (also on the Costa da Morte). So far, the collection has been known as the 'Ethnographic Community Museum' (Museo etnográfico veciñal). There was a local market, which made Ponte do Porto the place where people could assemble and stay into the night, dancing in the club and drinking in bars and taverns. Residents of the right bank of the river got together to collect interesting pieces, stored in a local house. All the items related to local history: old crafts, traditional lace making, emigration, and so forth. Nonetheless, rather than the collection itself, it was the circumstances of their visit that captured the authors' interest. To gain access to the collection, they were told to ask for the keys at neighbouring houses. The person who guided them expressed a great fondness for the pieces, as well as recounting experiences and emotions linked to the collection. The authors' role here turned out to be rather perverse and provocative. They remarked on how sad it was for the collection to be kept in such poor conditions, with things piling up, and got an immediate answer: 'This museum is of the people and for the people. It belongs to us' clearly a defence of local identity. Ponte do Porto's identity has been forged as 'other' to Camariñas, the municipal capital. As a market town, Ponte do Porto could compete with the capital. It boasted better accessibility by land, a stronger link with inland farming areas, and an important local 
fair where renowned Camariñas lace was sold by local producers (the so-called 'palilleiras'), and cattle dealers from places as far as the city of A Coruña were drawn to it. Lace-making (encaixe) had its golden age during the 19th century and early 20th century, when it used to be exported to South American countries. Nowadays, Camariñas is only a small town seeking socio-economic regeneration through tourism and cultural heritage. It is creating a lace-making museum (Museo do Encaixe) and has held a festival in Holy Week that attracted thousands of visitors. Thus Camariñas is now competing with Ponte do Porto through the commercialization of lace-making.

What is the difference between such unrecognized 'museums' and the official ones? This section describes an official museum in the region of Deza in the centre of Galicia. The museum is a private initiative located in a country house restored as lodgings. A number of objects are stored in the old upper storey of the house, including three beds, a cradle, radios and stereos, a sideboard, chests of drawers, chairs, washbasins, barber chairs, school desks, books, baskets dangling from walls, straw hats, and so forth. Everything was rather piled up and out of context. In another room the authors found a boat with creels. This was strange because the museum is located in a farming area, only linked to the ocean in terms of people going to the beach in the southern estuaries of Galicia. Recently, the promoter of this ethnographic collection enlarged the space of the museum and exhibited a new collection of objects. A large number of people from the PP - the Partido Popular, which was the dominant political party in Galicia almost continually from 1984 to 2005 , came to the opening.

The authors also visited the Ethnographic Pottery Museum of Buño in A Coruña province, created with sponsorship from the Bergantiños county foundation (Fundación Comarcal de Bergantiños ). The process of crafting pottery was recreated by means of idealized papier-mâché models. Placed in a functional modern building, the museum is a 'hyper-real exhibition' (Baudrillard 1993; Raposo 2000: 4), completely devoid of anthropological or any other kind of interpretive contextualization. Paradoxically, the museum is located just some yards away from a group of very ancient kilns, some of which were about to fall into ruin. Initially, A Coruña's provincial government collaborated with a local association on the restoration project, with touristic promotion and community development purposes in mind. At the time of the visit, however, the association was not receiving any support from the authorities. Here the idea that the past can be handed to us on a plate and that objects do not need to be interpreted seems to be widely assumed. Musealization is usually undertaken mimetically, in accordance with certain fashionable standards, without taking into account anything beyond the doors of the museum building. Social and community-related issues tend to be disregarded. In this case the ethnographic museum does not act as a reflective mirror for the experiences of the community, the chronotypes of which have been replaced with hyper-real elements. They are museums where there is a 
predominance of a descriptive vision and the objects are portrayed as in a Dutch landscape painting: in a static position and without narrative content; and in some cases the objects on exhibition do not have an aesthetic quality (Marcus 2000: 230).

So far, our first two examples have been representative of communitarian museology (Vergo 1989; Mattos Araujo and Oliveira Bruno 1995; Alonso Fernández 1999), characterized by the recreation and reinvention of a community and its symbolic boundaries (Cohen 1985) in regard to other rival communities. In our third example, the process of recognition of the museum as such is determined to a great extent by the political relationships existing between the museum's promoters and the public authorities. In our first two examples, appreciating the tensions relating to local socio-centric identity (Clifford 1999: 155) is crucial for understanding the creation of an ethnographic museum, whereas the lack of recognition on the part of public authorities stems from the promoters' unwillingness to submit to political control and appropriation. These museums are 'of the people and for the people'. In our third and fourth examples, official recognition strengthens hierarchical links - since certain favours are granted in return for obedience - between the authorities and the museum's promoters, although the existence of such links might be difficult to prove empirically. At the same time, the museum's promoters reinforce their position with regard to the local social structure and Galician political life. Thus, we gain a better insight into the use of the category 'relevant' and we see why scientific rigour and curatorial coordination have been pushed into the background. In short, the art-culture system (Clifford 1995: 257) in Galicia is associated with an ideological and institutional background that compels museum creators to undertake a bureaucratic pilgrimage (Roseman 2003) in order to obtain enough institutional support. Political criteria are thus crucial when it comes to according official status to new museums, whereas scientific, aesthetic, educative, and endogenous development criteria are widely disregarded.

\section{The representation of 'self' and 'other'}

So far certain legal, political, and administrative factors have been introduced to explain the creation and management of ethnographic museums in Galicia. This section deals with an additional important factor - the images of 'ourselves' and 'others' in Galician ethnographic museums. Ethnographic museums are institutions with the power to represent 'selves' and 'others', and their histories, from a particular point of view (Ames 1992; Carretero Pérez 1999). In a general way, Galician museums project an immutable, idealized image of the 'others' that Galicians once were and are currently ceasing to be. However, very few museums are encouraging a reflection on these issues, let alone a reflection on 'otherness'. The adoption of a generalized and stereotypical selfimage in almost every local and regional museum in Galicia relates to an anthropological discourse inherited from the past and enshrined by 
certain intellectuals and politicians. This idea can be illustrated with an example:

And we added that, with regards to Galicia - according to geographic conditions, particular ways of life, survival of certain traditions, habits, and customs - we must distinguish between three basic means of life: life in the mountains, life in the valleys and life on the coast. The General Directorate for Fine Arts (Dirección General de Bellas Artes), dependant on the Education and Science Ministry (Ministerio de Educación y Ciencia), complied with our proposals by ordering the creation of three Arts and Popular Customs museums. Thus, a Mountain Areas Museum was set up in the village of Cebrero, located in a mountainous area (Lugo province) and boasting a famous $9^{\text {th }}$ Century sanctuary considered to be an important landmark in the Pilgrims Way to Santiago de Compostela; a Valley Areas Museum, in Ribadavia (Ourense province), a town located in the Ribeiro region, very popular for its wines; and a Coastal Areas Museum, in the small fishing village of Combarro, Pontevedra, (. . .)".

(Chamoso Lamas 1974)

This quotation is from the founder and former director of the Pilgrimages Museum, located in Santiago de Compostela. Manuel Chamoso Lamas was the head of Fine Arts and Museums in Galicia during the period of the Franco dictatorship. This type of discourse has crystallized and is mimicked over and over again as a result of current management policies are promoted by government agencies and museum stakeholders concerned with cultural assets. The idea of establishing a Mountain Areas Museum, a Valley Areas Museum, and a Coastal Areas Museum, was based upon the idea that each of these geographical spaces represented a metonymic image of 'Galician' culture. Even the Museum of the Galician People (Museo do Pobo Galego) has promoted the exhibition of cultural artefacts in this mimetic way, avoiding any reference to anthropological ideas about social organization. This way of representing Galician culture has become the standard in museums. However, local-global connections that are so formative in Galician culture in the past and present are hardly ever dealt with, as in the case with migrations to Latin America, other parts of Europe and elsewhere in the world. Instead, these museums, with some exceptions, are conceived of as permanent exhibitions of stereotyped objects, disregarding plural or multifaceted identities that change over time. Those object-orientated museums only recreate a very particular and limited image of identity. Galician ethnographic museums and collections focus largely on displaying the rural world, technological backwardness, and androcentrism (male-centredness) in a manner that results in a representation of an essentialized Galician identity - as discussed below.

Symbolic processes, numerous tourist guides (Nogueira García 1998) and some well-known anthropological studies have helped create an inaccurate clichéd and essentialist image of Galicia as a rural country. Galician 
ethnographic museums also help to reinforce this rural cliché. This essentialist concept is usually represented by the material culture used historically by peasants and fishermen irrespective of social changes and the experiences of the objects' creators or users. It must be noted that there are some remarkable exceptions, such as the Ethnological Museum of Ribadavia and the Ethnographic Park of Allariz (both in the province of Ourense), which has generated a so-called 'Allariz Effect' (Sierra Rodríguez 2001: 550). However, the essentialist representations predominate and curiously, the forgers of such archaic images tend to be middle-class people from mid-sized towns or cities within Galicia, who take advantage of the artefacts created by rural 'others' in order to build up their own identities. Urbanites tend to assert an essentialized Galician identity, on the assumption that the rural world is more 'authentic' and 'ethnographic' than the urban world. Yet the agrarian world has generally been subordinate to the urban world, and is becoming more and more absorbed by it. That ethnographic otherness is imagined as some kind of 'noble savagery' in a rural context that has resisted outside influences for longer. Peasant and fishing populations served to confirm survivalist theses, because for many Galician nationalist intellectuals, Galicia was an ancient culture with its roots well-preserved among the peasants (see, for example, Fernández Prieto 1993; Villares 2004).

Another important aspect for our interpretation is that some of Galician ethnographers, such as Xaquín Lorenzo (1962), were influenced by German Cultural Historicism such as that of Fritz Krüger (1927; Medela 2005), who conducted fieldwork in Galicia and other parts of the Northwest of the Iberian Peninsula, and in 1927 wrote the book Die nordwestspanische volkskultur (also see Ros Fontana 2003; González Reboredo 2003). Michael Herzfeld (1987: 17) arrives at a similar conclusion for the Greek case. The exhibitions about rural life demonstrate the interest of members of the Galician bourgeoisie in popular customs, because they need that symbolic construction for the creation of their identity, to feel more authentic. As Pina-Cabral (1991) said, the same has happened in the North of Portugal.

The lack of a profound reflection on socio-cultural changes is such that hardly any museum, even those located in urban contexts, has taken into account the effects of urbanization and 'rurbanization' and they have certainly not recognized the new meanings of the rural spaces they intend to represent. New socio-cultural models (Souto González 2001) - suburban, periurban, counter-urban, commuter, post-rural, neo-rural, or 'rurban' (Pereiro Pérez 2005) - have been thoroughly disregarded. 'Ruralist' images are also characterized by identifying 'rural' with 'agrarian', failing thus to acknowledge the widespread abandonment of agrarian activities that has been taking place in Galicia (Sierra Rodríguez 2000). There is a strong link - not casual - between these processes of agrarian abandonment and the objects stored in ethnographic museums. In these museums it seems that we are losing paradise. Following Fabian (1983) and Hallam and Street (2000) we must ask, must museology be the science of disappearance? 
Our museums, fail to provide any interpretative clues that might throw light on changing reality, since their focus is on filling up the collective memory box with the intention of granting some sort of continuity for the generations to come. Rural images thus created tend to idealize and harmonize the local world by adopting the myth of a small community (Redfield 1947): rural, agrarian, static, religious, conservative, and of course, depoliticized and free of conflicts.

Another aspect of the essentialism associated with ethnographic museums is their androcentric, male-centred representation of Galician cultural identity. This image is subtle and subliminal enough to generally go unnoticed. The fact is that images of men dominate the display spaces in these museums, whereas women are seldom represented - in either objects or activities - and when they are, it is always in a role linked to domestic life. There is nothing there to remind us that women themselves have been economic producers in those contexts (Braña Rey, Mariño Costales and Mouriño López 1999), since such a male-centred memory disregards gendered lives.

This essentialism can easily be seen if one considers which artefacts are displayed and which ones are absent. Ethnographic museums have tended to largely display specific technologies used in agriculture and animal breeding, thereby creating a specific impression. Simultaneously, certain objects have been granted a special value as 'relics from a world on the way to extinction' (Clifford 1995: 241). Ethnographic museums, with the above-mentioned exceptions of those in Allariz and Ribadavia, have paid little if any attention to all the processes of agrarian modernization that have been undertaken in Galicia over the last centuries. Why should a sickle be preferred to a threshing machine as a museum piece and container of collective memory? To what extent has scientific interest been subordinated to aesthetics? Apparently, museums are in search of things already lost and disregard objects that have been gained, accumulated or transformed. The urgency to collect is reasserted and there is a growing concern about the objects being lost (Domínguez 1986). A culture's symbolic representation is thus maintained through the preservation of certain objects:

... boys and girls started to behave as treasure hunters, searching in lofts, threshing floors, sheds, in most cases becoming the saviours of old objects that were already sleeping the long dream of useless things (Ethnographic Museum of Mosteiro de Caaveiro's State School - A Capela - A Coruña). (Gran Enciclopedia Gallega 2000: 211)

Nevertheless, the idea of an urgent need to recover and preserve 'Galician' culture is a false one since we know that cultural heritage, and especially ethnographic museums, cannot cover all aspects of a given culture (Rodríguez Becerra 1997). And the images of technological backwardness tend to be idealized rather than explained or interpreted. Generally, the process of heritage creation results in a 'happy' product, since tourists and 
visitors, rather than witnessing misery, are prone to visit spaces free from conflict - let's say the 'memory of a happy Arcadia' (Sierra Rodríguez 2000). Instead, museums can and must be instruments for research on culture, and therefore, can and must be institutions producing knowledge with essentially social and educative purposes. The detachment of universities from ethnographic museums in Galicia is due to the lack of prominence of anthropology in the academy and partly to the fact that the research of ethnographers and folklorists from an earlier period have become anachronistic but still guide the design of displays in most Galician museums. Also, public administrations are more interested in inaugurating spaces than in funding their continual development over time. Additionally, art historians have gained more professional clout than anthropologists in the organization of museums. All of these factors act against ethnographic museums becoming centres of research.

To illustrate the impact of these essentialist images on visitors, the following comments were gathered from vistors to the Allariz Ethnographic Park in 1997:

- 'The history of our ancestors might be the history of farming.' Galicia' (Male, 43 years old, 8 /10 /1997)

- 'Coexistence, past and present in perfect harmony.' (Female, 38 years old , $18 / 10 / 1997)$

- 'Tradition.' (Female, 25 years old, November 1997)

- 'Galicia's past.' (Female, 27 years old, 25 /10 /1997)

- 'Nostalgia.' (Male and Female, 30 and 31 years respectively, 9-10-1997, with regards to Galician Toys Museum)

- 'Reminiscences of a reality still familiar to me. '(Female, 41 years, December 1997)

(Pereiro Pérez 1999: 97-110)

San Paio de Narla's Tower (municipality of Friol, province of Lugo) is a medieval building that holds an 'ethnographic museum' attached to Lugo's Provincial Museum. The display of objects with no regard to any context was extreme in this case. The perceptions of visitors fitted in perfectly with the image of ethnographic museums as storehouses for things fallen out of use or for the decorative exhibition of objects:

- 'What a beautiful thing, there was one like this in my grandfather's house'. (Female, approximately 50 years old, 1999)

- 'They fit really fine here, they're great decoration'. (Group of retired women form Ribadeo, 1999)

The image of the 'other' that ethnographic museums communicate is therefore effective in transmitting an essentialist identity to visitors and can be considered to be a hegemonic discourse from an ideological point of view. This impact on visitors entails a paradox with regards to a cultural 
tourism devoted to promote forgetfulness of the locals' history, experiences, and problems, which is unable to either educate or interpret. Therefore it displays a stereotyped and detached version of the local reality that is only experienced and known by the communities from the same regions (Boissevain 1996). Following Herzfeld's analysis of Greek identity (Herzfeld 1987: 10), within Galicia, the peasants are presented as underdeveloped, but outside of Galicia they are presented as having a common glorious heritage. To avoid such an oversimplified approach, a critical cultural memory should be promoted along the lines of local people's previous experiences either past or still in process.

\section{Conclusion}

An anthropological museum is a mirror, a window, and a way of symbolically representing identities, memories and histories. This representation is always selective, sometimes forgetting cultural diversity and theories pertaining to inter-cultural contact in the application (or non-application) of anthropological knowledge (Shelton 1992). In the Galician case, many museums are defined as 'ethnographic' both by their creators and visitors. These museums are strongly linked to essentialist ideas about ruralism, backwardness and a male-centred past. Likewise, the standards assumed by the administration and current legislation for ethnographic museums focus exclusively on the material objects collected, disregarding the anthropological discourses linked to those objects, the advice of experts, and research and educational objectives. Those standards are not only affecting the official recognition of some museums versus others, but also the images and discourses created by those museums. Galician ethnographic museums have been converted into spaces that only portray a selective rural tradition and rely on archaeological ideas about material culture.

In Galicia, therefore, the so-called 'ethnographic museums' are putting into practice - with certain remarkable exceptions - a game of collective 'anaesthesia', whereby much of the past is forgotten in order to selectively promote a particular Galician identity. Galician society is represented as an object outside of history and social structure, in temple-like museums or memory boxes, in line with one's wishes.

This raises some interesting new questions for further research such as why there is such a disregard for the anthropological idea that cultures are more and more interconnected. And are Galician anthropological museums becoming strikingly similar to Galician cemeteries? One can ask further why we are failing in some contexts to understand museums as continuous processes (De Varine 1997). Equally the question of why we do not understand them as spaces for intercultural communication and cross-cultural comparison (Shelton 1992) should be raised.

Shelton believes ethnographic museums ought to be like a door into other cultures, an instrument for understanding the relationship between cultures and human groups, instead of just presenting curiosities (Shelton 1992: 14). The complexity of a culture is reduced to a collection, suggesting 
that cultures are collections of objects (Handler 1988), and ethnography is an exercise in hunting and recollection (in a metonymic sense). The ethnographic-museological object shown in museums does not present an absolute truth, although it pretends to; its display cases are not a temple where objects are adored as religious figures (Hainard 1984: 189).

In Galicia, as in other societies, 'ethnographic museums' have been used in the construction of national identities since the early 1920s, but this project was interrupted by the Franco dictatorship and only restarted after the reintroduction of democracy in the 1970s. Today, the models, discourses and methods of representation are very similar to those used in the past. Images of 'self' and 'others' display a hegemonic idea about the past, and are presented in a dichotomous way - rural/urban; pre-industrial/industrial; traditional/modern - and with a high degree of symbolic effectiveness. The objectification of Galician culture is based upon a false notion of a homogeneous, folkloric and essentialist culture. It is our social function, as researchers, to interpret those processes critically and project them into cultural heritage and museums.

\section{Acknowledgements}

The authors wish to thank Sharon Roseman for her very important critical comments on this text, and to Monica Threlfall and the two anonymous reviewers for their helpful suggestions.

\section{Works cited}

Adorno, T.W. and Horkheimer, M. (1979 [1947]), Dialectic of Enlightenment, London: Verso.

Alonso Fernández, L. (1999), Introducción a la nueva museología, Madrid: Alianza Editorial.

Ames, M. (1992), Cannibal Tours and Glass Boxes. The Anthropology of Museums, Vancouver: University of British Columbia Press.

Augé, M. (1993), Los no-lugares. Espacios del anonimato. Una antropología de la sobremodernidad, Barcelona: Gedisa.

Baudrillard, J. (1993), 'Coleccionistas y coleccionismos', Revista de Occidente, 141, pp. 115-146.

Boissevain, J. (ed.) (1996), Coping with Tourists: European Reactions to Mass Tourism, Oxford: Berghahn Books.

Boniface, P. and Fowler, P. (1993), Heritage and Tourism in the Global Village, London: Routledge.

Braña Rey, F., Mariño Costales, M. and Mouriño López, E. (1999), ‘Trama y urdimbre: género y gestión patrimonial en Vilar de Santos 1998', in E. Fernández Paz and J.A. Torrico (eds.), Patrimonio cultural y museología. Significados y contenidos, Santiago de Compostela: Federación de Asociaciones de Antropología del Estado Español, pp. 81-88.

Calo Lourido, F. (ed.) (2004), O Museo de Xaquín Lourenzo, Vigo: A Nosa Terra.

Carretero Pérez, A. (1999), 'Museos etnográficos e imágenes de la cultura', in E. Aguilar Criado (ed.), Patrimonio etnológico. Nuevas perspectivas de estudio, Sevilla: Instituto Andaluz de Patrimonio Histórico, pp. 94-109.

Castro Seixas, P. (1997), 'Património, museu e dialogia', Trabalhos de Antropologia e Etnología, 37, pp. 21-40. 
Chamoso Lamas, M. (1974), 'La creación del museo del traje regional gallego', in Actas del III Congreso Nacional de Artes y Costumbres Populares, Zaragoza: Institución Fernando El Católico, pp. 347-50.

Clifford, J. (1995), Dilemas de la cultura. Antropología, literatura y arte en la perspectiva posmoderna, Barcelona: Gedisa._— (1999), Itinerarios transculturales, Barcelona: Gedisa.

Cohen, A. (1985), The Symbolic Construction of Community, London: Routledge.

De Varine, H. (1997), 'The Community Museum as a Continuing Process', Boletim Cultura e Património (Aveiro), 1997, pp. 136-39.

Domínguez, V. (1986), 'The Marketing of Heritage', American Ethnologist, 13, pp. $546-55$.

Fabian, J. (1983), Time and the Other. How Anthropology Makes Its Object, New York: Columbia University Press.

Fariña Busto, F. (1975a), 'Los museos gallegos', Grial, 49, pp. 312-24. (1975b), 'El museo y la exposición. Problemas en torno al museo de Combarro', Grial, 50, pp. 440-57.

- (2004), 'Xocas e os museos', in Actas do Congreso sobre Xaquín Lorenzo, Santiago de Compostela: Xunta de Galicia, pp. 197-204.

Fernández de Rota, J.A. (1996), 'La cultura de la permanencia en la era de la fugacidad', Revista de Antropología Social, 5, pp. 115-123.

Fernández Prieto, L. (1993), Labregos con ciencia, Vigo: Xerais.

García Fernández, J. (ed.) (1987), Legislación sobre patrimonio histórico, Madrid: Tecnos.

García Fernández, J. (2007), 'La regulación y la gestión del patrimonio históricoartístico durante la Segunda República (1931-1939)', in e-rph n. ${ }^{\circ} 1$ (http://www. revistadepatrimonio.es/revistas/numero1/legislacion/estudios/articulo.php). Accessed 8 January 2008.

González Reboredo, X.M. (2003), 'Características e importancia da colección fotográfica de W. Ebeling', in A terra e os homes. Fotografías de Walter Ebeling (1928-1933), Lugo: Deputación Provincial de Lugo, pp. 43-58.

Gran Enciclopedia Gallega (2000), ‘Colexio Público Mosteiro de Caaveiro’, Gran Enciclopedia Galega, 22 (Apéndice 2000), pp. 210-12.

Hainard, J. (1984), Objects préxtextes, objects manipulés, Neuchâtel: Musée d'Ethnographie.

Hallam, E. and Street, B. (eds.) (2000), Cultural Encounters. Representing 'Otherness', London and New York: Routledge.

Handler, R. (1988), Nationalism and the Politics of Culture in Quebec, Madison: The University of Wisconsin Press.

Hannerz, U. (1998), Conexiones transnacionales, Madrid: Cátedra.

Herzfeld, M. (1987), Anthropology Through the Looking-Glass. Critical Ethnography in the Margins of Europe, Cambridge: Cambridge University Press.

Instituto Galego de Estatística (2007), 'Cifras de poboación, Santiago de Compostela: Instituto Galego de Estatística', http://www:ige.eu/web/index.jsp?paxina=001 \&idioma=gl. Accessed 10 February 2008.

Karp, I. and Lavine, S.D. (eds.) (1991), Exhibiting Cultures: The Poetics and Politics of Museum Display, Washington: Smithsonian Institution Press.

Kirshenblatt-Gimblett, B. (1998), Destination Culture: Tourism, Museums and Heritage, Berkeley: University of California Press.

- (2001), 'La cultura de les destinacions: teoritzar el patrimoni', Revista de Etnologia de Catalunya, 14, pp. 44-61. 
Korff, G. (2002), 'Fremde (the Foreign, Strange, Other) and the Museum', Journal of the Society for the Anthropology of Europe, 2: 2, pp. 29-34.

Krüger, F. (1927), Die nordwestspanische volkskultur. Publisher unknown.

Llopart, D. (1994), 'Patrimoni etnològic versus museus etnològics', Aixa - Revista Anual del Museu Etnològic del Montseny, La Gabella, 6, pp. 10-13.

López Redondo, A, López de Prado Nistal, C. and Lemos Ramos, B. (1993), Censo de museos de Galicia. Normas para o inventario, Dirección Xeral do Patrimonio (Consellería de Cultura da Xunta de Galicia): Santiago de Compostela.

Lorenzo Fernández, X. (1962), Historia de Galicia. Etnografía. Cultura material, Buenos Aires: Editorial Nós.

- (1978), 'A Seición de Etnografía do Seminario de Estudos Galegos’, in Testemuños e perspectivas en homenaxe ao Seminario de Estudos Galegos, Sada: Ediciós do Castro, pp. 47-52.

Marcus, J. (2000), 'Towards an Erotic of the Museum', in E. Hallam and B.V. Street (eds.), Cultural Encounters. Representing 'Otherness', London and New York: Routledge, pp. 229-44.

Mato, A. (2001), O Seminario de Estudos Galegos na documentación que garda o Instituto Padre Sarmiento, Sada: Edicións do Castro.

Mattos Araujo, M. and Oliveira Bruno, M.C. (1995), A memória do .pensamento museológico contemporáneo. Documentos e depoimentos, São Paulo: Comité Brasileiro do ICOM.

Medela, J. (2005), 'Patrimonio da humanidade. A Raia é nos@', Arraianos, 2, pp. $22-25$.

Nogueira García, M. del C. (1998), 'A imaxe de Galicia a través das guías turísticas', Facultade de Xeografía e Historia - University of Santiago de Compostela, Unpublished paper.

Núñez Seixas, X.M. (2001), 'De Breogán a Pardo de Cela, pasando por América: notas sobre la imaginación del nacionalismo gallego', Historia Social, 40, pp. 53-78.

Pereiro Pérez, X. (1999), 'Patrimonialización, museos e arquitectura: o caso de Allariz', in E. Fernández Paz and J. Agudo Torrico (eds.), Patrimonio cultural y museología. Significados y contenidos, Santiago de Compostela: Federación de Asociaciones de Antropología del Estado Español, pp. 97-110.

- (2005), Galegos de vila. Antropoloxía dun espazo rurbano, Santiago de Compostela: Editorial Sotelo Blanco.

Pérez, Y.; Serrano, N. and Vilar, M. (1997), 'El desaparecido museo de Pías en el Balneario de Mondariz', in X.M. González Reboredo (ed.), Actas del III Congreso de Historia de la Antropología y Antropología Aplicada, Santiago de Compostela: Instituto Padre Sarmiento-CSIC, pp. 145-168.

Pike, K. (1967 [1954]), Language in Relation to a Unified Theory of the Structure of Human Behavior, The Hague: Mouton.

Pina-Cabral, J. (1991), Os contextos da antropologia, Lisboa: DIFEL.

Poulot, D. (1994), 'Identity as Self-Discovery: The Ecomuseum in France', in D.J. Sherman and I. Rogoff (eds.), Museum and Culture. Histories, Discourses, Spectacles, Minneapolis: University of Minnesota Press, pp. 66-84.

Raposo, L. (2000), Museus de arqueología e sítios arqueológicos musealizados. Identidades e diferenças, Lisboa: Museu Nacional de Arqueologia, Unpublished paper.

Redfield, R. (1947), 'The Folk Society', American Journal of Sociology, 52, pp. 293-308.

Rivière, G.H. (1989), La museología: curso de museología, textos y testimonio, Madrid: Akal. 
Rodríguez Becerra, S. (1997), 'Patrimonio cultural, patrimonio antropológico y museos de antropología', Boletín del Instituto del Patrimonio Histórico Andaluz, 28, pp. 42-52.

Ros Fontana, I. (2003), 'Walter Ebeling en el este de la provincia de Lugo (1928-1933). Imágenes de una investigación de la Escuela de Hamburgo en Galicia', in A Terra e os homes. Fotografías de Walter Ebeling (1928-1933). Lugo: Diputación Provincial de Lugo, pp. 13-41.

Roseman, S. (2003), 'Poniendo la artesanía gallega y el turismo rural gallego en el mapa global: políticas administrativas y propuestas locales', in C. Bueno and E. Aguilar (eds.), Las expresiones locales de la globalización: México y España, Ciudad de México: Grupo Editorial Miguel Ángel Porrúa, CIESAS, and Universidad Iberoamericana, pp. 381-404.

Sierra Rodríguez, X.C. (1996), 'A planificación museística en Galicia no horizonte do ano 2000: criterios de programación', in J.M. García Iglesias (ed.), Presente e futuro dos museos en Galicia, Santiago de Compostela: Fundación Alfredo Brañas, pp. 147-162.

(1999), 'A obra de Xaquín Lorenzo Fernández, instrumento para a patrimonialización e musealización antropolóxica en Galicia', Raigame, 9, pp. 71-74.

- (2000), 'Procesos de patrimonialización en Galicia', in X.M. González Reboredo (ed.), Proxecto Galicia. Antropoloxía, XXIX, A Coruña: Editorial Hércules, pp. 382-470.

(2001), 'O patrimonio cultural e os museos, instrumentos para a construcción e a representación das identidades. Notas sobre (e dende) Galicia', in X.M. González Reboredo (ed.), Etnicidade e nacionalismo. Simposio Internacional de Antropoloxía, Santiago de Compostela: Consello da Cultura Galega, pp. 527-569.

- (2002), Programación y gestión. La recuperación y la investigación del patrimonio etnológico en Galicia, Museo Etnológico de Ribadavia: Ourense, Unpublished paper.

Shelton, A. (1992), 'The Recontextualization of Culture in UK Museums', Anthropology Today, 5, pp. 11-16.

Stocking, G. (1985), Objects and Others: Essays on Museums and Material Culture, Madison: University of Wisconsin Press.

Souto González, X.M. (2001), Planeamento estratéxico e mercadotecnia territorial, Vigo: Eixo Atlántico.

Vergo, P. (ed.) (1989), The New Museology, London: Reaktion Books.

Walsh, K. (1992), The Representation of the Past: Museums and Heritage in the PostModern World, London: Routledge.

Villares, R. (2004), Historia de Galicia, Vigo: Galaxia.

Xunta de Galicia (1995), Lei do Patrimonio Cultural de Galicia, Santiago de Compostela: Xunta de Galicia.

\section{Contributor details}

Xerardo Pereiro is an anthropologist who received his doctoral degree in Social Anthropology from the University of Santiago de Compostela (Galicia), on 'rurbanism', urbanization processes, and 'rurban' spaces in Galicia. He has been a researcher in the anthropology departments of the Complutense University of Madrid, the University of Edinburgh (Scotland) and ISCTE (Lisbon). He won the first 'Vicente Risco' Prize, the most important Galician award in the Social Sciences (1994) and the 'Fitur' award (2007) jointly with Cebaldo de León for their research about Kuna ethnotourism in Panamá. After a spell at the University Fernando Pessoa in Porto, he became Head of Applied Anthropology at the University of Trás-os-Montes e Alto Douro (Portugal). Today, his main research focus is on 
museums, cultural heritage and tourism in Galicia, Portugal and Panamá (Kuna Yala). Contact: University of Trás-os-Montes and Alto Douro, Pólo de Chaves, Apartado 61, 5401-909, Chaves, Portugal.

E-mail: xperez@utad.pt

Manuel Vilar is an anthropologist who has worked in the Galician Pedagogical Museum (Santiago de Compostela) and other ethnographic museums in Galicia. He has a MSC in 'Cultural Heritage and Identities' from the University of A Coruña. He has conducted fieldwork research on 'popular religion' in Galicia. For the past ten years, he has worked on ethnographic museums, cultural heritage and development in Galicia.

E-mail: MVILARAL@telefonica.net 